\title{
TRACE METAL ACCUMULATION IN VEGETABLES GROWN IN INDUSTRIAL AND SEMI-URBAN AREAS - A CASE STUDY
}

\author{
N. SRINIVAS ${ }^{1 *}-$ S. RAMAKRISHNA RAO ${ }^{2}-$ K. SURESH KUMAR ${ }^{1}$ \\ ${ }^{1}$ Department of Environmental Studies, GITAM Institute of Science, GI TA M University, \\ Visakhapatnam 530 045, A.P, India; \\ ${ }^{2}$ Department of Civil Engineering, College of Engineering, Andhra University, Visakhapatnam, \\ A.P, India \\ (phone:+91-0891-2840456; Fax: +91-08912790032) \\ *Corresponding author \\ e-mail:drsrinivas@gitam.edu \\ (Received $13^{\text {th }}$ September 2006 ; accepted $6^{\text {th }}$ July 2009)
}

\begin{abstract}
The main sources of trace metals to plants are the air or soil media from which trace elements are taken up by the root or foliage. The air, soil and vegetable samples were collected from Industrial, Semi-urban and rural areas and were analysed for $\mathrm{Pb}, \mathrm{Zn}, \mathrm{Ni}$ and $\mathrm{Cu}$. The rural area is free from contaminant sources and is treated as control. From each representative area composite samples of Tomato, Lady's finger, Capsicum and leafy vegetable Bimli were collected and anlysed for $\mathrm{Pb}, \mathrm{Zn}, \mathrm{Ni}$ and $\mathrm{Cu}$. The air environments in Industrial and Semi-Urban areas are enriched with the four trace metals, but the concentrations were within the permissible levels. This indicates that, despite the close proximity of the agricultural lands to high emitting industrial sources, soils do not seem to have been contaminated by atmospheric deposition. Remarkable differences were observed between the trace metal content in vegetables of rural areas with semi-urban and industrial areas. In industrial area Nickel, Zinc were reported in higher concentrations in tomato and capsicum where as in semi urban area the concentration of $\mathrm{Cu}$ is 2-3 times higher in tomato and lady's finger on comparison with the rural vegetables. Based on the air accumulation factor and concentration factor calculations, the trace metals of $\mathrm{Pb}$ and $\mathrm{Zn}$ in industrial and semi-urban areas were found to be receiving the contributions from both atmospheric and soil inputs in all the four crops.
\end{abstract}

Keywords: trace metals, vegetables, air accumulation factor, concentration factor

\section{Introduction}

Rapid industrialization and urbanization during this century resulted in an increase of metal contamination in soils. The main sources of trace metals to plants are the air or soil from which metals are taken up by the root or foliage. Some trace metals are essential in plant nutrition, but plants growing in a pollute environment can accumulate trace elements at high concentrations, causing a serious risk to human health. (Huchabee et al.1983; Hovmand et al.1983; Kabata-pendias and Pendias, 1984; Alloway, 1990; Vousta et al. 1996; Sharma et al.2004).

The uptake of metal concentration by roots depends on speciation of metal and soil characteristics and type of plant species etc. Consequently, metal mobility and plant availability are very important when assessing the effect of soil contamination on plant metal uptake, as well as translocation and toxicity or ultra structural alterations (Luo and Rimmer,1995; Sresty and Madhava Rao,1999; Chandra sekhar et al. 2001).

Atmospheric metals are deposited on plant surfaces by rain and dust. Several authors have shown a relationship between atmospheric element deposition and elevated element concentrations in plants and topsoils, especially in cities and in the vicinity of emitting factories (Andersen et al.1978; Pilegaard, 1978; Chirgawi, 1989; 
Larsen et al.1992; Sunchez et al.1994; Harrison and Vousta et al.1996; Srinivas et al. 2002). Airborne submicron particles are also filtered out on plant surfaces, constituting a substantial, but unknown, contribution to the atmospheric supply. Indirect effects of air pollutants through the soil are also great interference, because of the large - scale sustained exposure of soil to both wet and dry depositions of trace elements.

Widespread interest in trace metal accumulation in plant systems has emerged only over the last three decades, and several research articles reported concentrations of a number of trace elements in the local crops and other plants as a consequence of anthropogenic emissions (Bernhard et al. 2004 ; Bernhard et al. 2004 ; Wong et al. 2001). The present study was aimed to find out the trace metal concentration in vegetables grown in industrial and semi-urban areas in relation with air and soil growth media.

\section{Materials and methods}

\section{Study Area}

Visakhapatnam, often called a city of destiny, has been selected for the case study since numerous sources emit trace metals including several major and minor industries located within the city. Majority of industries such as refineries, fertilizers are located in industrial and semi-urban areas. In both the areas the vegetables are cultivated in a close proximity to the emission sources of trace metals. Basing on the field study, three study areas were selected representing different environmental backdrops. The selected sites are Auto Nagar (Industrial area), Rajeev Nagar (Semi - Urban area) and Chintala Agraharam (Rural or Control area). The samples were collected for a period of two years from 2000 - 2002 (Fig.1.). Air and Soil samples were collected bimonthly and vegetable samples were collected seasonally and analyzed for trace metals in air, soil and vegetables.

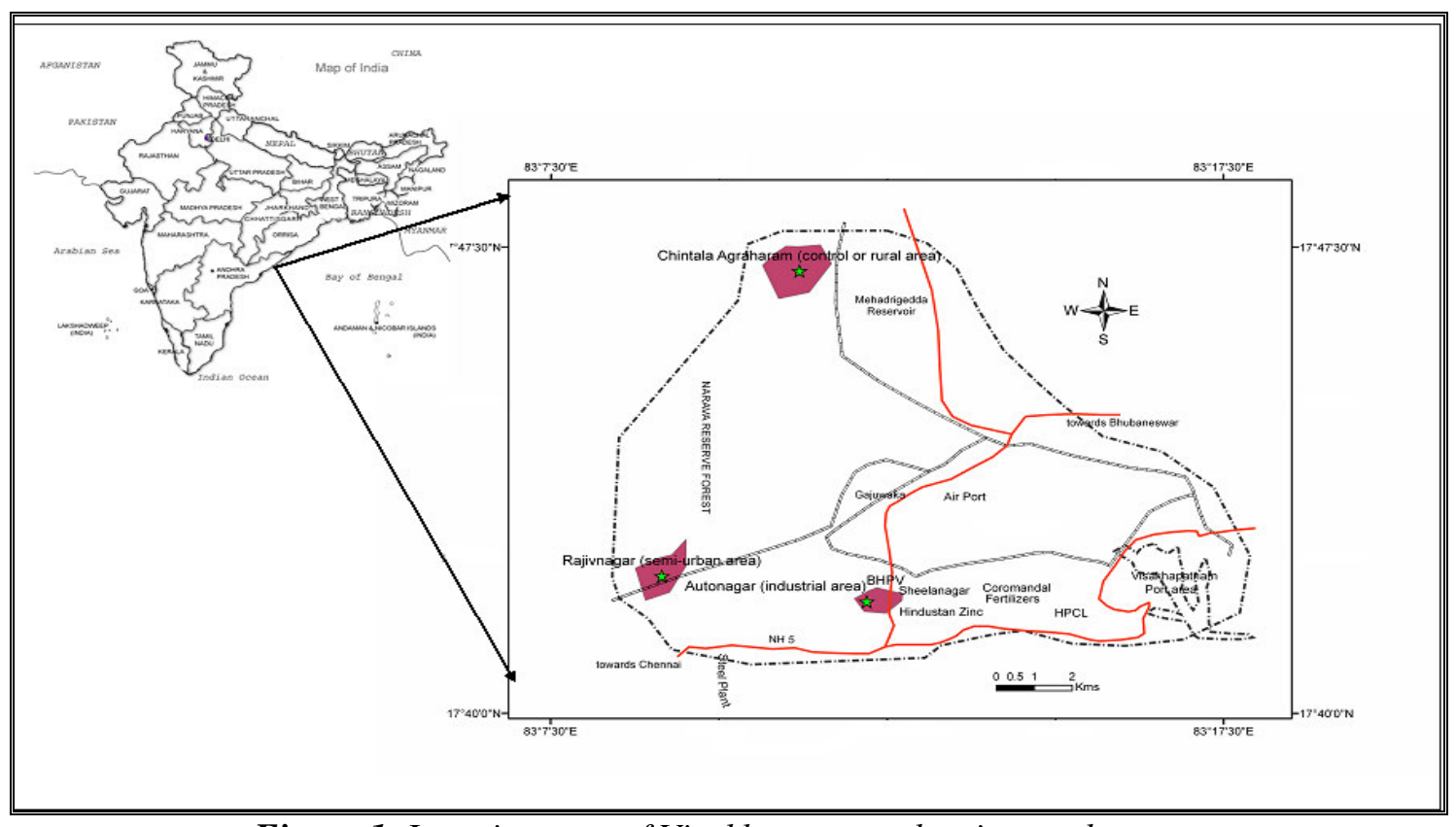

Figure 1. Location map of Visakhapatnam showing study areas 
Suspended Particulate Matter (SPM) are collected bimonthly by using High Volume Samplers (HVS) (Envirotech, APM - 420) from two stable residential communities for 8 hours duration (9-00A.M to 5-00 P.M) from each representative area (i.e. Industrial, semi-urban and rural) for two successive years. The collected air particulate matter treated with concentrated $\mathrm{HNO}_{3}$ acid for elemental analysis (Miroslav and Vladimir 1999). Field experiments were conduced during pre-monsoon (February - May) and post-monsoon (July - January) seasons for two successive years. From each representative area composite samples of vegetables like Tomato (Lycopersicon esculentum Mill), Lady's finger (Abelmoschus esculentus Linn.), Capsicum (Capsicum annuum Linn.) and leafy vegetable Bimli (Hibiscus cannabinus Linn) are collected from different sampling sites.

For trace metal analysis from each harvest a total of 20 plants were taken at random for analysis. The dried plant samples were digested with $\mathrm{HClO}_{4}$ and Conc. $\mathrm{HNO}_{3}$ for trace metal analysis by using Atomic Absorption Spectrophotometer and Inductively Coupled Plasma Emission Spectroscopy (ICP -ES).

The Air Accumulation Factor and Concentration factor were calculated to find out the origin of trace metals in vegetables by using the following formulas (Chandra sekhar et al. 2001).

\section{Equations}
A. A. F. $=$
Conc. of metal in Vegetable grown in Indu. Area / Conc.of metal in Air of Indu. area
Conc. of metal in Vegetable grown in Cont. area / Conc. of metal in Air of Cont. area
C. F. $=$
Conc. of metal in Vegetable grown in Indu. Area / Conc.of metal in Soil of Indu. area
Conc. of metal in Vegetable grown in Cont. area / Conc. of metal in soil of Cont. area

\section{Statistical Analysis}

Statistical significance observed differences between samples was determined by Student's $t$-test and ANOVA test. Differences were considered to be significant at $\mathrm{p} \leq$ 0.05 and highly significant at $\mathrm{p} \leq 0.001$, level of significance.

\section{Results and Discussion}

\section{Trace metals in air}

The air borne particulate matter in industrial \& semi-urban environments found to be highly enriched with trace metals such as $\mathrm{Pb}, \mathrm{Zn}, \mathrm{Ni}$ and $\mathrm{Cu}$ as given in Table 1 .

However, the concentration of the four metals in the air was found to be within the tolerance limits (Mudakavi and Narayana, 1998). The $\mathrm{Pb}$ concentration in industrial area reported as $1.46 \mu \mathrm{g} / \mathrm{m}^{3}$. whereas the $\mathrm{Zn}, \mathrm{Ni}$ and $\mathrm{Cu}$ concentrations were reported higher in semi-urban area compared with industrial area. The four trace metals of industrial and semi-urban area have shown significant difference $(>0.05)$ with control (rural) area. It was may be due to the deposition of air pollutants at higher rates resulting from the dispersion of atmospheric pollutants. 
Table 1. Trace metal content in Suspended Particulate Matter $\left(\mu \mathrm{g} / \mathrm{m}^{3}\right)$ and soil $(\mathrm{mg} / \mathrm{kg})$.

\begin{tabular}{|c|c|c|c|c|c|c|c|c|}
\hline \multirow[t]{2}{*}{ Study area } & \multicolumn{4}{|c|}{ Air } & \multicolumn{4}{|c|}{ Soil } \\
\hline & $\mathbf{P b}$ & $\mathrm{Zn}$ & $\mathrm{Ni}$ & $\mathbf{C u}$ & $\mathbf{P b}$ & $\mathrm{Zn}$ & $\mathrm{Ni}$ & $\mathbf{C u}$ \\
\hline $\begin{array}{l}\text { Industrial area } \\
\text { Auto Nagar }\end{array}$ & $\begin{array}{l}1.467^{*} \\
\pm 0.41\end{array}$ & $\begin{array}{l}2.453^{*} \\
\pm 0.93\end{array}$ & $\begin{array}{l}0.496^{* *} \\
\pm 0.15\end{array}$ & $\begin{array}{l}0.414^{* *} \\
\pm 0.99\end{array}$ & $\begin{array}{l}47.8 \\
\pm 3.30\end{array}$ & $\begin{array}{l}49.7^{* *} \\
\pm 5.24\end{array}$ & $\begin{array}{l}28.98^{* *} \\
\pm 2.50\end{array}$ & $\begin{array}{l}31.1^{* *} \\
\pm 3.28\end{array}$ \\
\hline $\begin{array}{l}\text { Semi Urban } \\
\text { area } \\
\text { (Rajeev Nagar) }\end{array}$ & $\begin{array}{l}1.376^{*} \\
\pm 0.52\end{array}$ & $\begin{array}{l}4.985^{\text {** }} \\
\pm 0.87\end{array}$ & $\begin{array}{l}0.977^{* *} \\
\pm 0.34\end{array}$ & $\begin{array}{l}0.648^{* *} \\
\pm 0.14\end{array}$ & $\begin{array}{l}15.1^{* *} \\
\pm 2.4\end{array}$ & $\begin{array}{l}42.9^{2.27} \\
\pm 6.3\end{array}$ & $\begin{array}{l}16.8^{* * 2} \\
\pm 2.7\end{array}$ & $\begin{array}{l}11.3 \\
\pm 0.91\end{array}$ \\
\hline $\begin{array}{l}\text { Rural area } \\
\text { C-Agraharam }\end{array}$ & $\begin{array}{l}0.689 \\
\pm 0.53 \\
\end{array}$ & $\begin{array}{l}1.691 \\
\pm 0.30 \\
\end{array}$ & $\begin{array}{l}0.087 \\
\pm 0.01 \\
\end{array}$ & $\begin{array}{l}0.116 \\
\pm 0.02 \\
\end{array}$ & $\begin{array}{l}8.1 \\
\pm 0.82 \\
\end{array}$ & $\begin{array}{l}32.2 \\
\pm 1.75 \\
\end{array}$ & $\begin{array}{l}8.7 \\
\pm 0.5 \\
\end{array}$ & $\begin{array}{l}7.7 \\
\pm 0.45 \\
\end{array}$ \\
\hline
\end{tabular}

* Significant at 0.05 level

** Significant at 0.001 level

$\mathrm{n}=12$

\section{Trace metals in soils}

The trace metal concentrations in soils of industrial, semi-urban and rural areas are given in Table 1. The trace metal concentrations of $\mathrm{Pb}, \mathrm{Zn}, \mathrm{Ni}$ and $\mathrm{Cu}$ in industrial and semi-uraban soils were statistically significant at 0.05 level over control (rural) area and the concentrations are within the permissible limits for agricultural soils (Alloway, 1990; Aswathanarayana, 1999).This indicates that, despite the close proximity of the cultivated land to high - emitting industrial sources, agricultural soil does not seem to have been significantly contaminated by atmospheric deposition. This may be due to low deposition rate resulting from the dispersion of atmospheric pollutants and variations in soil physico - chemical characteristics.

\section{Trace metals in vegetables}

The $\mathrm{Pb}, \mathrm{Zn}, \mathrm{Ni}$ and $\mathrm{Cu}$., metal concentrations in the vegetables of Tomato, $\mathrm{L}$. Finger, Capsicum and Bimli were examined during the present study (Figs. 2, 3).

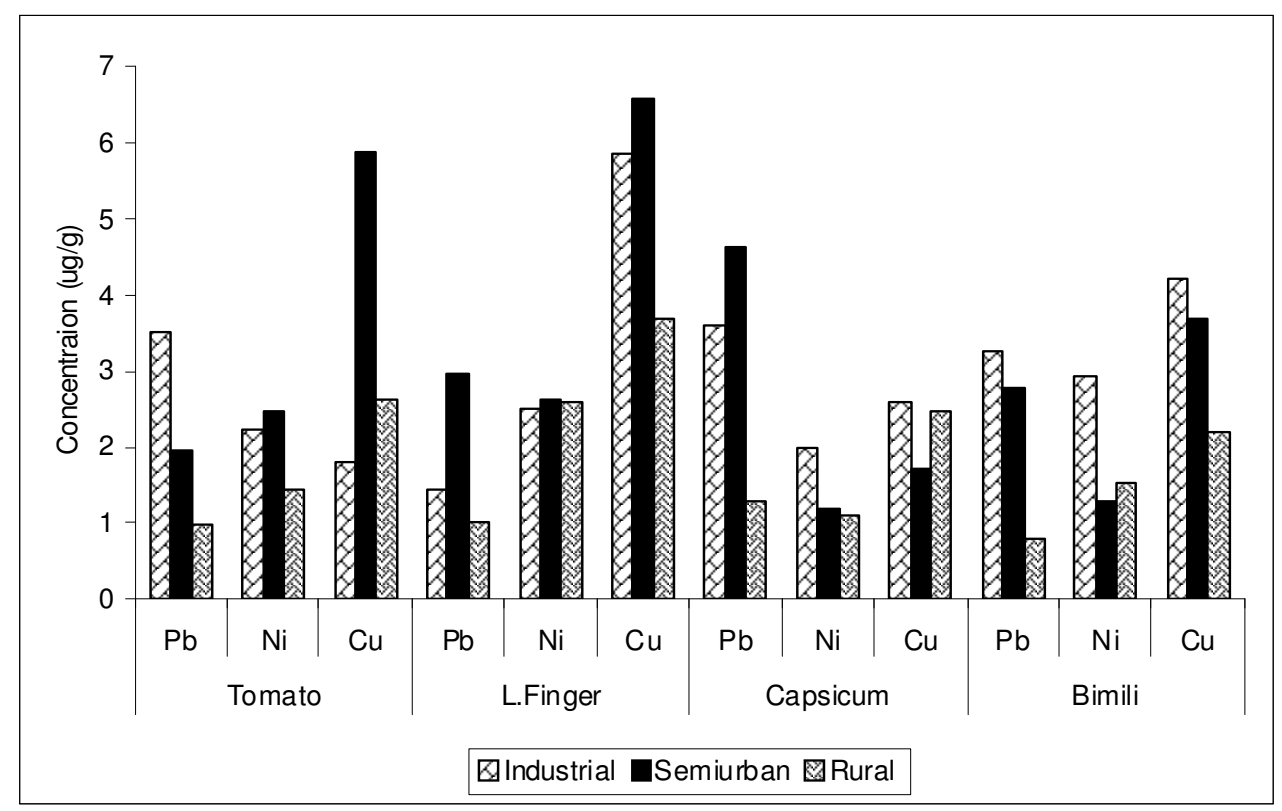

Figure 2. Lead, Nickel and Copper content in Vegetables 


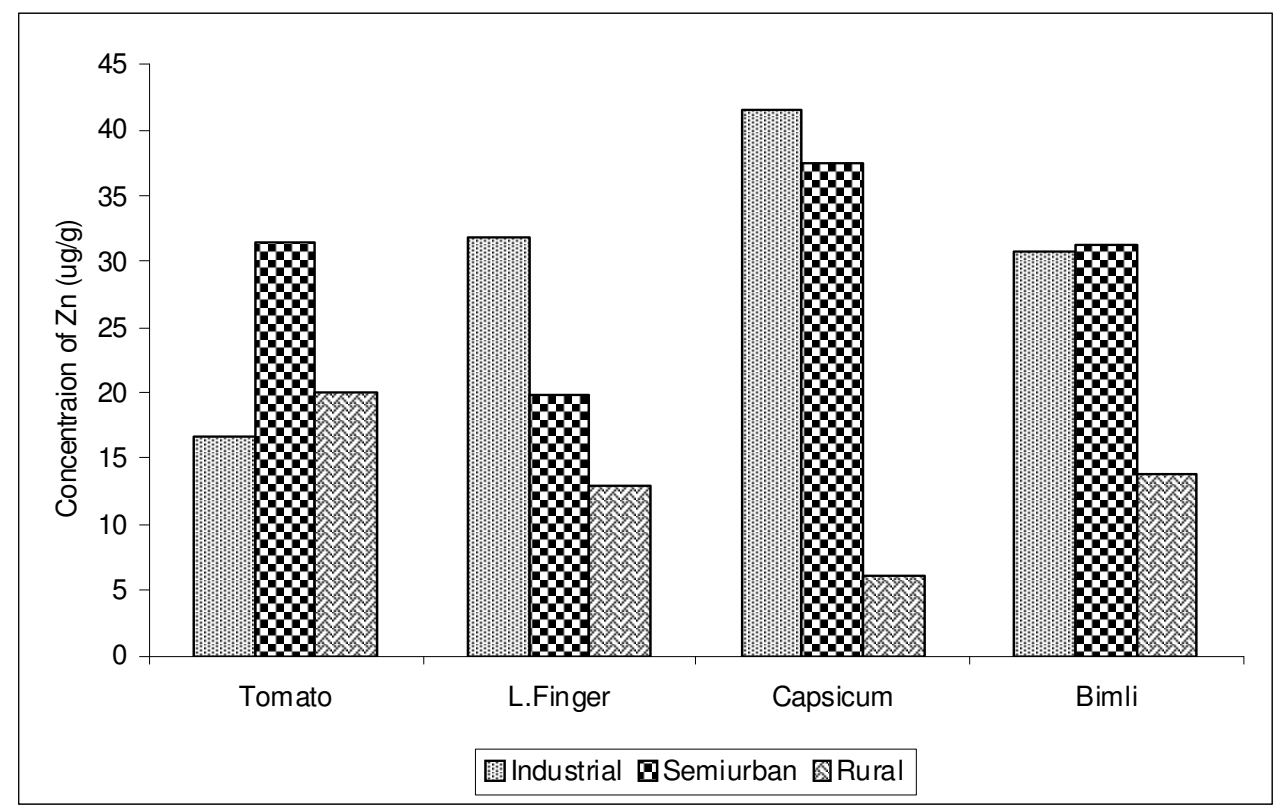

Figure 3. Zinc content in Vegetables

\section{Lead}

In general, $\mathrm{Pb}$ concentrations in vegetation have increased in recent decades owing to human activities. The $\mathrm{Pb}$ content of edible parts of plants growing in uncontaminated areas generally range from 0.05 to $3.0 \mu \mathrm{g} / \mathrm{g} \mathrm{d} . \mathrm{w}$. In the present study rural area reported $\mathrm{Pb}$ concentration in vegetables in the range of 0.88 to $1.02 \mu \mathrm{g} / \mathrm{g}$ in all the four crops. Whereas in industrial and semi-urban areas the $\mathrm{Pb}$ concentration in vegetables in the range of 1.72 to $4.63 \mu \mathrm{g} / \mathrm{g}$ and the average concentration is $3.55 \mu \mathrm{g} / \mathrm{g}$. It is clearly showing that, the air or soil of urban environments is contributing the $\mathrm{Pb}$ by various sources. The permissible limit of lead in vegetables for human consumption is $2.0-2.5$ $\mu \mathrm{g} / \mathrm{g}$ dry weight (Samara et al.1992). In the present study the $\mathrm{Pb}$ concentration in vegetables cultivated in industrial and semi-urban areas reported above the permissible levels. Hence, it is necessary to kept lead levels as low as possible in the two environments.

\section{Zinc}

Environmental pollution of $\mathrm{Zn}$ greatly influences the concentrations of this metal in plants. In ecosystems where $\mathrm{Zn}$ is an airborne pollutant, the tops of plants are likely to concentrate more $\mathrm{Zn}$ on the other hand; plants grown in $\mathrm{Zn}$ contaminated soils accumulated a great proportion of the metal in roots (Kabata and Pendias,1992). In the present study the $\mathrm{Zn}$ concentration in vegetables grown in industrial and semi - urban areas reported in the range of 19.93 to $41.46 \mu \mathrm{g} / \mathrm{g}$ and in rural area in the range of 12.99 to $20.01 \mu \mathrm{g} / \mathrm{g}$. Among the four vegetable crops, capsicum and leafy vegetable Bimli accumulated higher levels of $\mathrm{Zn}$. In all the study areas the $\mathrm{Zn}$ concentration reported in the four vegetables are within the permissible limits (i.e. 10-50 $\mathrm{g} / \mathrm{g}$ ) for human consumption (Samara et al.1992).

\section{Nickel}

Vegetables have more nickel than animal products. The concentration of $\mathrm{Ni}$ in plants generally ranges from 0.05 to $5 \mu \mathrm{g} / \mathrm{g}$ dry weight. According to WHO (1984) the 
$\mathrm{Ni}$ concentration in vegetables and fruits reported in the range of 0.02 to $2.7 \mu \mathrm{g} / \mathrm{g}$. The elevated concentrations of Nickel and Copper in plant tissue reflect man made pollution. The $\mathrm{Ni}$ content in vegetables from the industrial and semi - urban areas of Visakhapatnam did not show large variability between the study areas. In the present study the Nickel concentration in industrial and semi-urban areas reported in the range of 1.29 to $2.62 \mu \mathrm{g} / \mathrm{g}$. whereas in rural area it was reported in the range of 1.1 to 1.53 $\mu \mathrm{g} / \mathrm{g}$. These concentrations of $\mathrm{Ni}$ in industrial and semi-urban areas were found at concentrations normally observed in vegetables grown in uncontaminated soils.

\section{Copper}

Copper is essential trace element to plants and the amount of copper present in plants varies with the copper content of soil on which it is grown. The copper concentration in food stuffs reported in the range of 1.75 to $9.26 \mu \mathrm{g} / \mathrm{g}$. (Nath et al.1982). In the present study the copper content in Semi-urban area reported in the range of 1.7 to $6.58 \mu \mathrm{g} / \mathrm{g}$ with an average of $4.46 \mu \mathrm{g} / \mathrm{g}$. whereas in the industrial and rural areas the average $\mathrm{Cu}$ concentration reported as 3.60 and $2.74 \mu \mathrm{g} / \mathrm{g}$ respectively. The concentration of $\mathrm{Cu}$ in plants varied much with dependent near by factors like proximity industries and use of fertilizers and $\mathrm{Cu}$ based fungicides. The maximum permissible limit for $\mathrm{Cu}$ in vegetables is $50 \mu \mathrm{g} / \mathrm{g}$ (Samara et al.1992.) and in the present study the concentration of $\mathrm{Cu}$ well within the limits in all the four vegetables.

The trace metals $\mathrm{Pb}, \mathrm{Zn}, \mathrm{Ni}$ and $\mathrm{Cu}$ have shown variations in concentration among the vegetables and sampling sites. In the present study, the concentration of $\mathrm{Zn}, \mathrm{Ni}$ and $\mathrm{Cu}$ trace elements in vegetables of Tomato, Lady's finger, Capsicum and leafy vegetable Bimli is low and comparable with the results of Samara et al. (1992). But remarkable differences were observed between the trace metal content of rural areas with semi-urban and industrial areas. In industrial area $\mathrm{Ni}, \mathrm{Zn}$ was reported in higher concentrations in tomato and capsicum compared with control areas. In semi-urban area the concentration of $\mathrm{Cu}$ in tomato and lady's finger reported 2-3 times higher than the rural vegetables. It was known that the trace metal concentrations in harvested vegetables often show large variation from year to year, even at the same location in the field. This is probably due to variable emission rates, atmospheric transport and deposition process, and plant uptake. (Vousta et al.1996). The increased value of trace metal was determined for $\mathrm{Pb}$

in vegetables grown in industrial areas. The four trace metals concentrations in industrial and semi-urban areas have shown a significant difference with control (rural) area.

\section{Air accumulation factor and Concentration factors}

The origin of trace metals in vegetables is accumulation due to atmospheric deposition or transfer from soil or both. The AAF and CF values are given in Table 2.

In the case of $\mathrm{Pb}$ and $\mathrm{Zn}$ both $\mathrm{AAF}$ and $\mathrm{CF}$ factors are high in all the four crops grown in industrial and semi-urban areas. The $\mathrm{Ni}$ and $\mathrm{Cu}$ have not shown any significant trend and the values are more or less similar in all the four crops. The $\mathrm{Pb}$ and $\mathrm{Zn}$ are contributing in considerable levels by both soil and air media in all the four vegetable species. However, the variation in AAF and CF values can be ascribed to a number of factors such as chemical speciation of trace metals, atmospheric and soil concentrations and variation in uptake etc. (Vousta et al.1996). 
Table 2. Air Accumulation Factors $(A A F)$ and Concentration Factors $(C F)$ in vegetable crops at different study areas

\begin{tabular}{|c|c|c|c|c|c|}
\hline \multirow{3}{*}{ Crop } & \multirow{2}{*}{ Trace metal } & \multicolumn{2}{|c|}{ AAF } & \multicolumn{2}{c|}{ CF } \\
\cline { 2 - 6 } & & Industrial & Semi-Urban & Industrial & Semi-Urban \\
\hline \multirow{4}{*}{ Tomato } & $\mathrm{Pb}$ & 1.665 & 0.981 & 0.601 & 1.050 \\
\cline { 2 - 6 } & $\mathrm{Zn}$ & 0.574 & 0.533 & 0.540 & 0.846 \\
\cline { 2 - 6 } & $\mathrm{Ni}$ & 0.270 & 0.151 & 0.463 & 0.882 \\
\cline { 2 - 6 } & $\mathrm{Cu}$ & 0.190 & 1.081 & 0.168 & 4.117 \\
\hline \multirow{4}{*}{ Capsicum } & $\mathrm{Pb}$ & 0.662 & 1.457 & 0.246 & 1.561 \\
\cline { 2 - 6 } & $\mathrm{Zn}$ & 7.350 & 2.261 & 6.911 & 5.005 \\
\cline { 2 - 6 } & $\mathrm{Ni}$ & 1.167 & 0.089 & 0.287 & 1.916 \\
\cline { 2 - 6 } & $\mathrm{Cu}$ & 0.443 & 0.319 & 0.391 & 1.215 \\
\cline { 2 - 6 } & $\mathrm{Pb}$ & 1.297 & 1.783 & 0.468 & 1.911 \\
\cline { 2 - 6 } & $\mathrm{Zn}$ & 4.693 & 2.082 & 4.411 & 4.607 \\
\cline { 2 - 6 } & $\mathrm{Ni}$ & 0.314 & 0.097 & 0.537 & 0.564 \\
\hline \multirow{4}{*}{ Bimli } & $\mathrm{Cu}$ & 0.293 & 0.123 & 3.852 & 0.470 \\
\cline { 2 - 6 } & $\mathrm{Pb}$ & 1.913 & 1.727 & 0.690 & 1.851 \\
\cline { 2 - 6 } & $\mathrm{Zn}$ & 1.537 & 0.771 & 1.445 & 1.707 \\
\cline { 2 - 6 } & $\mathrm{Ni}$ & 0.337 & 0.075 & 0.576 & 0.436 \\
\cline { 2 - 6 } & $\mathrm{Cu}$ & 0.533 & 0.299 & 0.471 & 1.140 \\
\hline
\end{tabular}

\section{Correlation analysis}

Correlation analysis applied among sampling sites, vegetable plants and among trace elemental concentrations in vegetables. The data was presented in Table 3.

Table 3. Correlation analysis among study sites, trace metals and vegetables.

\begin{tabular}{|l|l|l|l|}
\hline $\mathbf{n}=\mathbf{1 2}$ & Industrial & Semi - urban & Rural \\
\hline Industrial & 1 & & \\
\hline Semi - urban & $0.882^{* *}$ & 1 & \\
\hline Rural & $0.679^{* *}$ & $0.801^{* *}$ & 1 \\
\hline
\end{tabular}

\begin{tabular}{|l|l|l|l|l|}
\hline $\mathbf{n}=\mathbf{1 2}$ & Lead $(\mathbf{P b})$ & Zinc $(\mathbf{Z n})$ & Nickel $(\mathbf{N i})$ & Copper $(\mathbf{C u})$ \\
\hline Lead $(\mathbf{P b})$ & 1 & & & \\
\hline Zinc $(\mathbf{Z n})$ & $0.619^{*}$ & 1 & & \\
\hline Nickel $(\mathbf{N i})$ & 0.038 & 0.121 & 1 & 1 \\
\hline Copper $(\mathbf{C u})$ & -0.142 & 0.221 & 0.454 & 1 \\
\hline
\end{tabular}

\begin{tabular}{|l|l|l|l|l|}
\hline $\mathbf{n}=12$ & Tomato & Lady's finger & Capsicum & Bimli \\
\hline Tomato & 1 & & & \\
\hline Lady's finger & $0.751^{* *}$ & 1 & & \\
\hline Capsicum & $0.735^{* *}$ & $0.931^{* * *}$ & 1 & \\
\hline Bimli & $0.846^{* * *}$ & $0.950^{* * *}$ & $0.970^{* *}$ & 1 \\
\hline
\end{tabular}

* Significant at 0.05 level, ** Significant at 0.01 level 
High significant correlation coefficients were found between the sampling sites of industrial and semi urban, semi-urban and rural. Correlation between industrial and rural region also exist at 0.05 level. This attributes various industrial and urban pollution sources may effect the trace metal composition in vegetables by soil and air pollution.

Among four trace metals, strong correlation was found between $\mathrm{Pb}$ and $\mathrm{Zn}$ and no correlation with $\mathrm{Ni}$ and $\mathrm{Cu}$. This is probably due to variation in uptake mechanism by plants. A strong correlation between all four vegetables species observed. It indicates that the chemical composition of growth media is the major factor influencing the chemical composition of plants.

\section{Conclusion}

Among the four trace metals concentrations of $\mathrm{Zn}, \mathrm{Ni}$ and $\mathrm{Cu}$ in vegetables were found relatively low in industrial and semi-urban areas and their concentrations are within the permissible limits for human consumption. The average $\mathrm{Pb}$ concentrations in vegetables grown in industrial area reported in higher levels $(>2.5 \mu \mathrm{g} / \mathrm{g})$ in all the four crops and it is necessary to kept $\mathrm{Pb}$ levels in both air and soil environments as low as possible.

The trace metal content of the agricultural soils was within the standard limits for agricultural soils. However, rising levels of trace metals are observed in industrial and semi-urban soils compared to rural soils. The air borne particulates in industrial and semi-urban areas are enriched with trace metals particularly $\mathrm{Pb}, \mathrm{Zn}, \mathrm{Ni}$ and $\mathrm{Cu}$ and are being emitted by various industrial and transport sectors.

The AAF and $\mathrm{CF}$ factors for $\mathrm{Pb}$ and Zinc are high in industrial and semi-urban areas and contributing those trace elements in to vegetables through air or soil or both. However different vegetable species accumulate different metals, depending on plant available metal species/forms of heavy metals rather than the total concentration in the soil. Dietary intake of leafy vegetables constitutes a major source of accumulation of heavy metals in human body. The detrimental impact of these metals becomes apparent only after decades of exposure.

Acknowledgements. Authors are grateful to University Grants Commission for financial support and GITAM University for encouragement and providing facilities to carryout this work.

\section{REFERENCES}

[1] Andersen, A., Hovmand, M.F., Johnson I. (1978): Heavy metal deposition in the Copenhagen area. - Environmental Pollut. 17: 133-151.

[2] Alloway, B.J. (1990): Heavy Metals in Soils, Blackie, Glasgow, UK.

[3] Aswathanarayana U. (1999): Soil Resources and the Environment. - Oxford \& IBH Publishing Co. Pvt. Ltd, New Delhi.

[4] Bernhard Zarcinas, A., Che Fauziah Ishak., Mike McLaughlin, J., Gill Cozens (2004): Heavy Metals in Soils and Crops in Southeast Asia 1. Peninsular Malaysia, Environmental Geochemistry and Health 26: 343-357.

[5] Bernhard Zarcinas, A., Che Fauziah Ishak., Mike McLaughlin, J., Gill Cozens (2004): Heavy Metals in Soils and Crops in Southeast Asia 2 Thailand. - Environmental Geochemistry and Health 26: 359-371.

[6] Chandra Sekhar, K., Rajni Supriya, K., Kamala, C.T., Chary, N.S., Nageswara Rao T., Anjaneyulu Y. (2001): Speciation, accumulation of heavy metals in vegetation grown on 
sludge amended soils and their transfer to human food chain - a case study. Toxicological and Environmental chemistry 82: 33-34.

[7] Huchabee, J.W., Sanz Diaz, F., Janzen, S.A., Solomon, J. (1983): Distribution of Mercury in vegetation at Almaden, Spain. - Environ.Pollut. 30: 211-224.

[8] Hovmand, M.F., Tjell, J.C., Mosbaek, H. (1983): Plant uptake of airborne Cadmium. Environ. Pollut. 30: 27-38.

[9] Harrison, R.M., Chirgawi M.B. (1989): The assessment of air and soil as contributors of some trace metals to vegetable plants. I: Use of filtered air growth cabinet. - Sci. Total Environ. 83: 13-34.

[10] Kabata-Pendias, A., Pendias, H. (1984): Trace elements in soils and plants. - CRC Press, Boca Raton, USA.

[11] Kabata-Pendias, A. Pendias. H. (1992): Trace Elements in Soil and Plants, $2^{\text {nd }}$ Edn. Lewis, Boca Boca Raton FL, USA, 365.

[12] Larsen, E.H., Moseholm, L., Nielsen M.M. (1992): Atmospheric deposition of trace elements around point sources and human health risk assessment. II: Uptake of arsenic and chromium by vegetables grown near a wood presentation factory. - Sci. Total Enviro. 126: 263-275.

[13] Luo, Y., Rimmer D.L. (1995): Zinc-Copper interaction affecting plant growth on a metal contaminated soil. - Environ Pollut. 88: 79-83.

[14] Mudakavi, J.R., Narayana. B.V. (1998): Toxic heavy metal contamination of the soil and biota. Part II. - Environmental Implications, Indian Journal of Environmental Protection 18(2): 101-108.

[15] Miroslav, R. Vladimir N.B. (1999): Practical Environmental Analysis. - Royal Society of Chemistry, Cambridge, UK.

[16] Nath, R., Lyall, V., Chopra, R., Prasad, R., Paliwal, V., Gulati, S., Sharma, N. Chanadan., R. (1982): Assessment of Environmental Pollution of Cadmium in North India. - Bull. Post. Grad. Instt., 16: 202-208.

[17] Pilegaard K. (1978): Air borne metals and Sulphur dioxide monitored by epiphytic lichens in an industrial area. - Environ Pollut. 17: 81-92.

[18] Samara, C., Misaelides, P., Tsalev, D., Anousis I., Kouimtzis Th. (1992): Trace elements distribution in vegetables grown in the industrial area of Thessaloniki, Greece. Fresenius Environ. Bull. 1: 577-582.

[19] Sunchez-Camazano, M., Sanchez-Martin, M.J., Lorenzo L.F. (1994): Lead and cadmium in soils and vegetables from urban gardens of Salmanca (Spain) - Sci. Total Environ. 146-147: 163-168.

[20] Sresty,T.V.S. Madhava Rao. K.V. (1999): Ultra structural alteration in response to zinc and nickel stress in the root cells of Pigeon pea. - Journal of Environmental and Experimental Botany 41: 3-13.

[21] Srinivas, N., Vinod Kumar, B., Suresh Kumar K. (2002): Lead Pollution in Roadside Plant in Visakhapatnam. - Journal of Environmental Studies and Pol 5(1): 63-68.

[22] Sharma, O.P., Bangar., Rajesh Jain K.S., Sharma P.K. (2004): Heavy metals accumulation in soils irrigated by municipal and industrial effluent. - Journal of Environmental Science and Engineering. 46(1): 65-73.

[23] Vousta, D., Gramanis, A., Samara C. (1996): Trace elements in vegetables grown in an industrial area in relation to soil and air particulate matter. - Environmental Pollut. 94: 325-335.

[24] WHO (1984): Guidelines for drinking water quality, Vol. II, health criteria and other supporting information. - World Health Orgnisation Geneva.

[25] Wong, J.W.C., Lai, K.M., Su, D.S. Fang, M. (2001): Availability of Heavy Metals for Brassica Chinensis grown in an acidic loamy soil amended with a domestic and an industrial sewage sludge - Water, Air and Soil Pollution 128: 339-353. 